\title{
GCGR wt Allele
}

National Cancer Institute

\section{Source}

National Cancer Institute. GCGR wt Allele. NCI Thesaurus. Code C157479.

Human GCGR wild-type allele is located in the vicinity of $17 q 25.3$ and is approximately 10 $\mathrm{kb}$ in length. This allele, which encodes glucagon receptor protein, is involved in hormonedependent signaling. Mutation of the gene is associated with type 2 diabetes mellitus and glucagon cell hyperplasia and neoplasia. 